\title{
THE NUMBER OF EMPLOYEES, BASIC STATISTICAL INDICATOR OF LABOUR MARKET EVOLUTION. COMPARATIVE STUDY BASED ON DATA FROM BACAU COUNTY AND THE CENTRAL REGION OF MOLDOVA
}

\author{
Phd. student Vasilica-Lăcrămioara Ciomârtan \\ Academy of Economic Studies of Moldova \\ Economist at Statistical County Directorate Bacau \\ lacri_vasi@yahoo.com
}

\begin{abstract}
The comparative approach to the evolution of the number of employees at the end of the year is aimed at illustrating the situation of the existing labour market in Bacau County of Romania and the Central Region of the Republic of Moldova over a period of 6 years (2011-2016). The dynamic analysis, with the latest available data of the above mentioned indicator, refers not only to the situation of each territorial unit (Bacau County or the Central Region), but also to a comparative analysis of the situation recorded in each of the two countries, Romania and the Republic of Moldova. In order to identify the existing gaps, data on the number of employees are analysed by gender and forms of ownership. In order to quantify the situation in the two territorial units for statistics regarding the labour market, a rather small number of indicators were taken into account due to lack of their dissemination on the desired administrativeterritorial units.
\end{abstract}

\section{Keywords}

Number of employees as at 31st December; dynamics of number of employees; forms of ownership; gender gaps

\section{JEL Classification}

E24; C19; J16

\section{Introduction}

Any economic activity involves the labour factor alongside the other factors of production. Labour statistics, as a branch of official statistics, studies the number of employees, the structure, the dynamics and utilization of labour resources of national economy, labour remuneration (forms of salary, average salary and salary funds, salary fund structure) and its productivity .

Labour statistics are brought to the attention of data users, researchers, all those needing this kind of information, through a variety of statistical publications produced by the institutes of statistics. Labour force balance provides information on labour resources, civilian active population, civilian employment, and the number of employees as at the 1st of January. The results of the Household Labour Force Survey provide information, by various characteristics, of civilian active population, civilian employment, ILO unemployment, inactive population. Also, a series of indicators are disseminated, such as indicators of employment (average number of employees, number of employees as at 31st December), of working conditions (work accidents and injuries, conflicts of interest, strikes triggered in accordance with legal procedures), salary earnings (average monthly gross salary, average monthly net salary, average salaries in October), vacancies, continuing vocational training. 
The reduced number of labour indicators analysed in this paper is mainly due to lack of their availability for the desired territorial level (county for Romania and region for the Republic of Moldova). Therefore, data on the number of employees at the end of the year are analysed only by gender and by forms of ownership.

\section{Short methodological presentation}

The most recently published indicators related to a 6-year period have been extracted from the databases of the National Institute of Statistics of Romania and the National Bureau of Statistics of the Republic of Moldova, so as to be able to follow their dynamic evolution.

In order to perform this comparative analysis, a few methodological aspects need to be presented. The year 2011 was the starting year for the analysis, as the data disseminated by the National Bureau of Statistics of the Republic of Moldova became comparable starting this year due to scope changes. Starting this year, data on the number of employees are obtained from economic and social units with 1 and more employees and from all budgetary institutions.

\section{Statistical analysis of the number of employees at the end of the year}

Employees are the most important segment of the employed population, and the main source of income for this category is salary or nominal salary income, gross and net. At the end of 2016, the number of employees in Bacau County was 11,114, that is $2.1 \%$ of the total number of Romanian employees, while on 31st December 2016, the Central Region numbered 124,117 employees, that is $17.3 \%$ of the total number of employees of the Republic of Moldova.

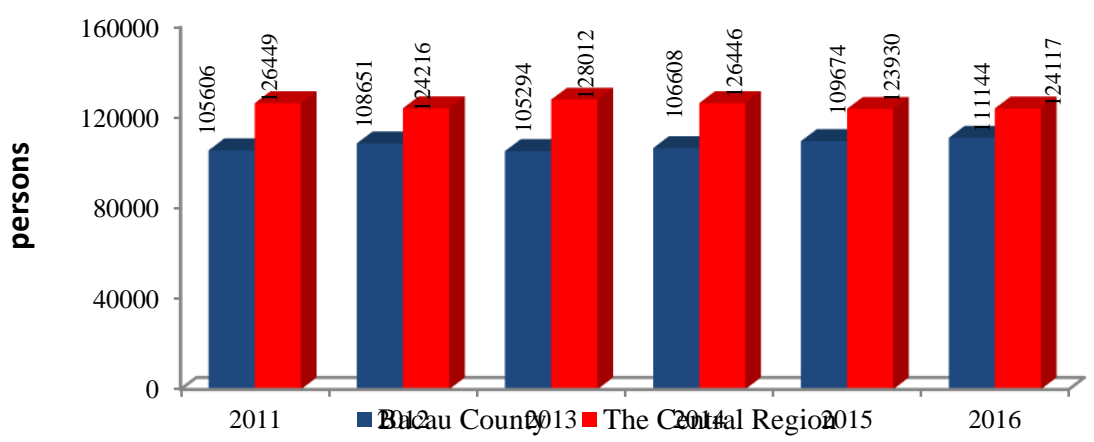

Figure 1: Number of employees as at 31st December, Bacau County and the Central Region (2011-2016) (persons)

Source: www.insse.ro and www.statistica.md

Despite the increase in the number of employees in Bacau County during the analysed period, Romania recorded a slight decrease of the percentage of this indicator of the value registered at national level, from 2.3\% in 2011 and 2012 to 2.2\% in 2013-2015, reaching only $2.1 \%$ in the final year of the analysis. This is not the case with the Central Region, where the increase in the number of employees coincided with an increase of the percentage at national level (the maximum of $17.5 \%$ in the period 2013-2014), and its decrease led to a decrease in value of the structure. 


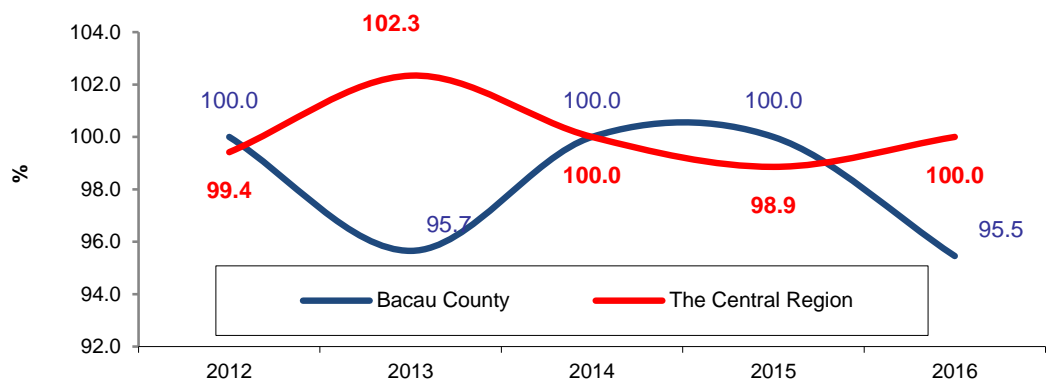

Figure 2: Dynamics of the structure of number of employees compared to previous year as at 31st December, Bacau County and the Central Region of the Republic of Moldova (\%)

Source: processing of the data collected from www.insse.ro and www.statistica.md

The dynamics of number of employees as at 31st December for Bacau County, compared to the previous year, follows approximately the same trend registered at national level, but with values below those recorded at national level, except for 2012, when the number of employees at county level increased by $2.9 \%$, while at national level there was an increase of $2.5 \%$. It is also worth mentioning the decrease by $3.1 \%$ at the end of 2013 for Bacau County, the number of Romanian employees being $0.5 \%$ higher than in the previous year. Whereas positive dynamics of this indicator are registered at Bacau County and Romania levels, these periods are marked by the drop in the number of employees in the Central Region and the Republic of Moldova. Practically, the periods of increase in the number of employees at Bacau County and Romania levels are decreasing periods for the Central Region and the Republic of Moldova. The end of 2013 registered 3.1\% more employees in the Center Region compared to the same period in the previous year, with an increase of $0.5 \%$ in the Republic of Moldova. The trend in the number of employees registered in the Central Region is similar to the one registered at national level in the Republic of Moldova, with the mention that for the years 2013 and 2016 the dynamics of the Region is superior to that recorded at national level.

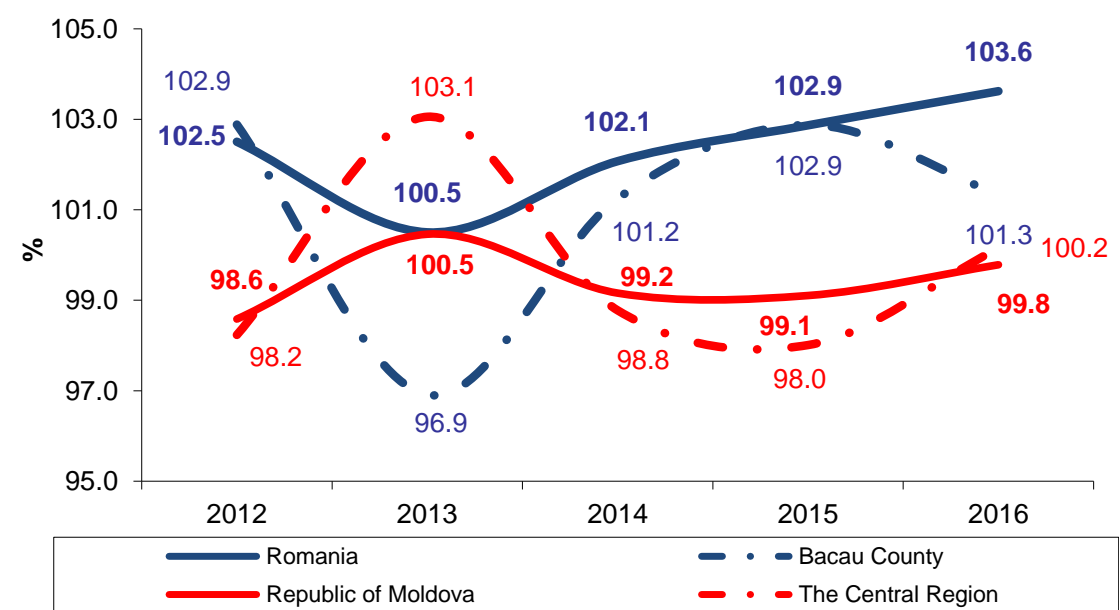

Figure 3: Dynamics of number of employees compared to previous year as at 31st December, Bacau County and Romania, the Central Region and the Republic of Moldova (\%)

Source: processing of the data collected from www.insse.ro and www.statistica.md 
The analysis by gender shows that the number of male employees at the end of the year in Bacau County is higher than that of female employees, whereas the situation at the Central Region level is quite opposite, with the number of female employees exceeding the number of male employees.

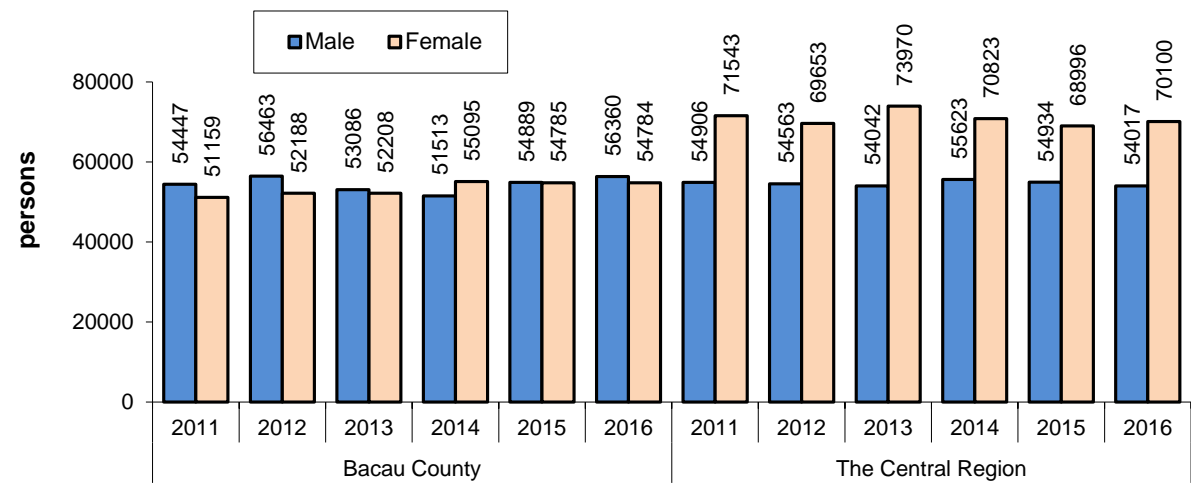

Figure 4: Number of employees by gender as at 31st December, Bacau County and the Central Region, 2011 - 2016 (persons)

Source: www.insse.ro and www.statistica.md

Whereas in Bacau County there is an increase in the share of female population from a minimum of $48.0 \%$ in 2012 to $51.7 \%$ in 2014, the share of women in the Central Region remained significantly higher than that of men, for the entire analysed period.

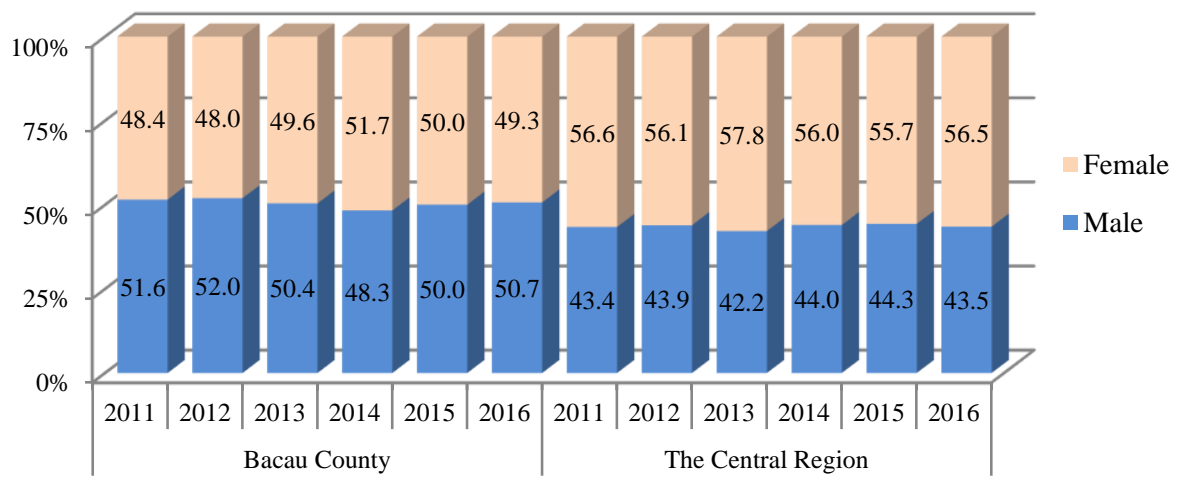

Figure 5: Evolution of the structure of number of employees by gender as at 31st December, Bacau County and the Central Region, 2011 - 2016 (\%)

Source: $\underline{\text { www.insse.ro and www.statistica.md }}$

Thus, there is a slight decreasing trend for the proportion of male employees per 100 female employees at Bacau County level, from 106 persons in 2011 to 103 persons in 2016. The number of male employees per 100 female employees at the Central Region level indicates slightly oscillating values of the proportion of males, which records the same value of 77 people in the first and last year of the analysed period, and reaches a maximum of 80 persons at the end of 2015 . 


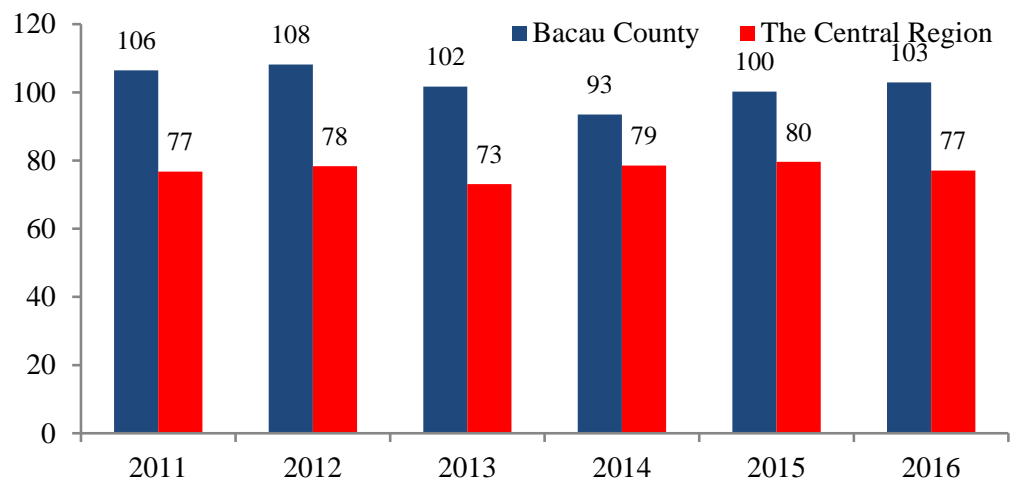

Figure 6: The proportion of male employees per 100 female employees as at 31st December, Bacau County and the Central Region, 2011-2016 (persons)

Source: processing of the data collected from www.insse.ro and www.statistica.md

At Bacau County level, the dynamics of gender, compared to previous year, shows considerable differences, namely while the number of male employees decreases, the number of female employees increases, and vice versa, except for the year 2012, when there is growth in both numbers $(+3.7 \%$ for men and $+2.0 \%$ for women) compared to 2011.

The same scenario is witnessed in the case of the Central Region: relatively positive changes in the number of female employees, simultaneously with relatively negative changes in the number of male employees. The exeptions to this trend are at the end of 2012 , compared to 2011, when the number of female employees decreased by $2.6 \%$ and the male one by $0.6 \%$, and at the end of 2015 when the decrease was of $2.6 \%$ in women and $1.2 \%$ in men.

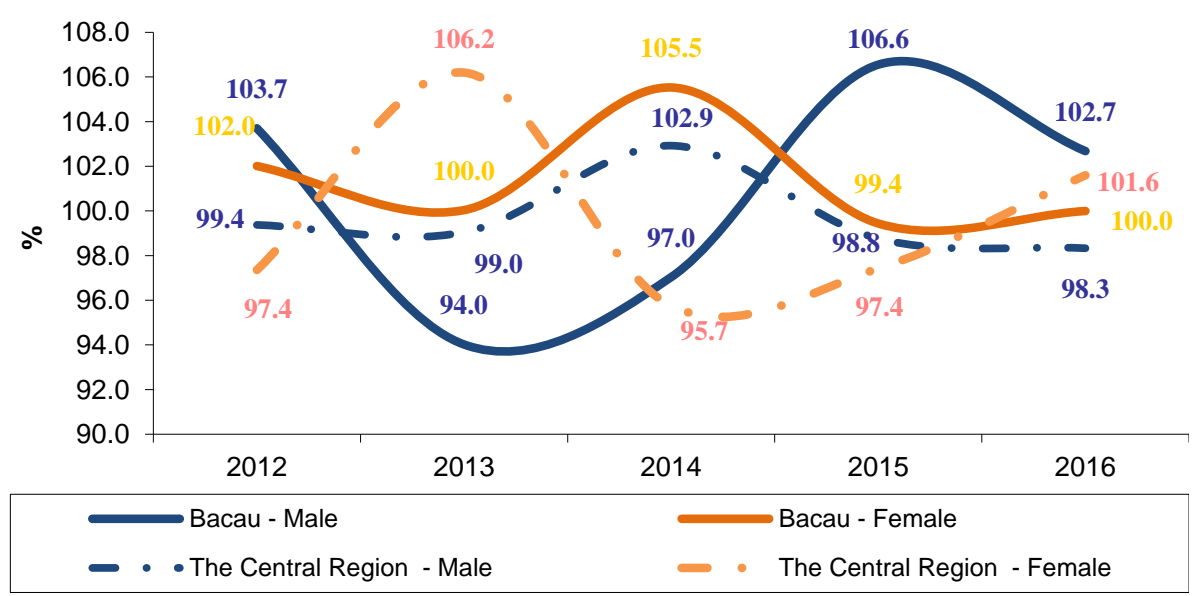

Figure 7: Dynamics of number of employees compared to previous year, as at 31st December, by gender, Bacau County and the Central Region (\%)

Source: processing of the data collected from www.insse.ro and www.statistica.md

Compared to the end of 2011, the number of employees registered at Bacau County level as at 31 st December 2016, increased by $5.2 \%$ as a result of the increase in the number of female employees by $7.1 \%$, and by $3.5 \%$ in the number of males, rises which were lower than the ones recorded at national level. Compared to the same point in time, the number of employees in the Central Region at the end of 2016 decreased by 
$1.8 \%$ ( $-2.0 \%$ for females and $-1.6 \%$ for males), their negative dynamics being lower than the ones recorded in the Republic of Moldova.

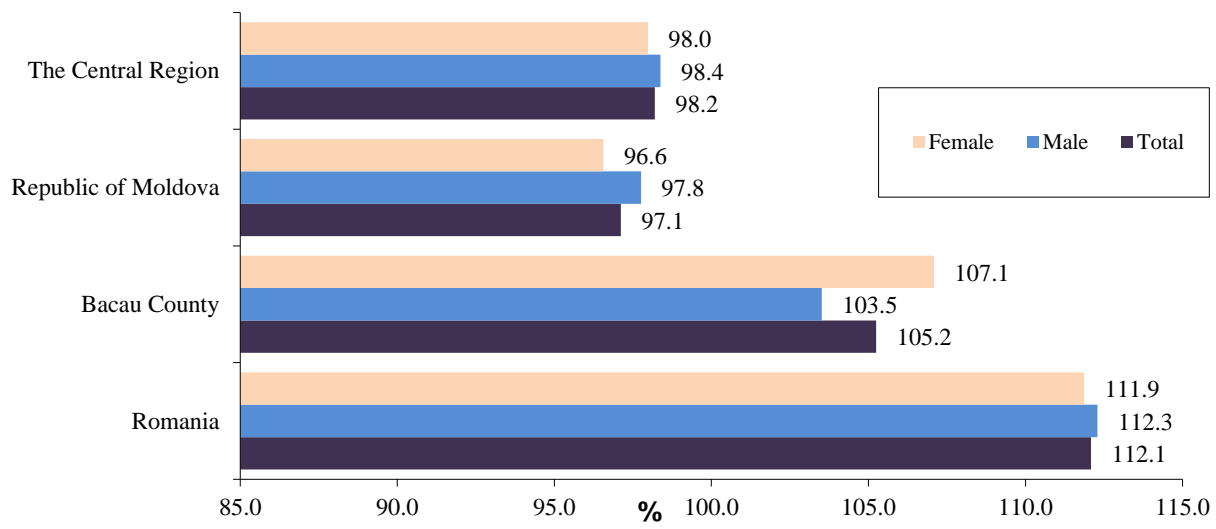

Figure 8: Dynamics of number of employees compared to 2011 as at 31st December 2016, by total and by gender, Bacau County and Romania, the Central Region and the Republic of Moldova, $(\%)$

Source: processing of the data collected from www.insse.ro and www.statistica.md

Analysed by forms of ownership, considerable differences can be observed between the situation in Bacau County and that in the Central Region. Whereas at the end of 2016, the public sector in Bacau concentrated $27.8 \%$ of the number of employees, at the same point in time, the Central Region held over $52 \%$ of the number of employees. In both Bacau County and the Central Region, compared to the end of 2011, there is a slight tendency to change the structure, to decrease the percentages in the public sector $(-1.7$ pp for Bacau County and -1.8 pp for the Central Region).

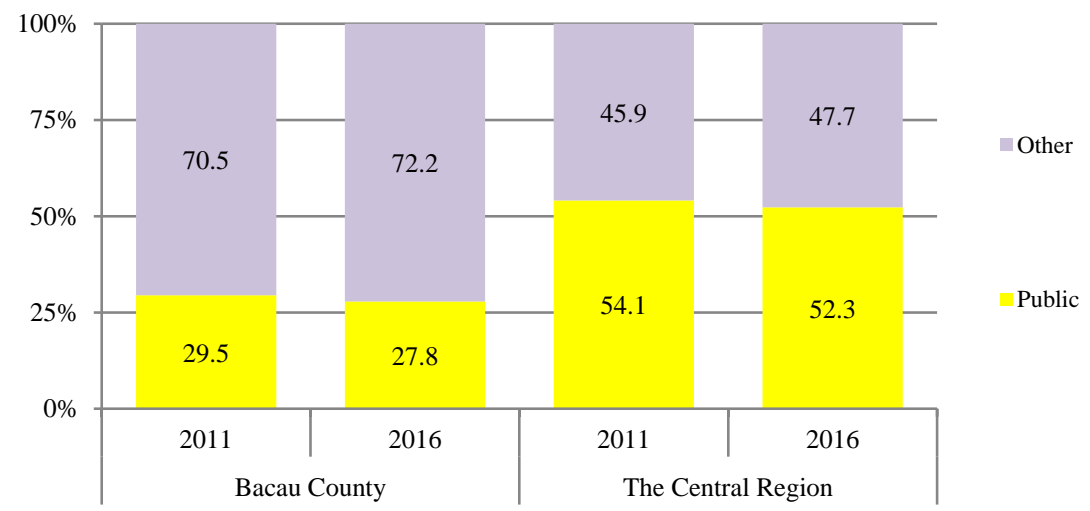

Figure 9: The structure of number of employees as at 31st December, by forms of ownership, Bacau County and the Central Region, 2011 and 2016 (\%)

Source: processing of the data collected from www.insse.ro and www.statistica.md

As can be seen in figure 10, the dynamics of the number of employees in the public sector of the Central Region, compared to the previous year, experiences continuous decrease, whereas in Bacau County there is a slight increase in the number of employees during the last 2 years of the analysis $(+1.1 \%$ at the end of 2015 and $+1.5 \%$ at the end of 2016). The number of employees within the other forms of ownership, in both Bacau County and the Central Region, presents year-to-year fluctuations as well as 
diametrically opposed situations: when there is an increase in number of employees in other forms of ownership in Bacau County, there is a decrease in number of employees in the Central Region. For example, the maximum decrease of this indicator in Bacau County was recorded at the end of 2013 compared to 2012 (-3.4\%), while within the same period, also the maximum increase of this indicator was recorded in the Central Region $(+7.4 \%)$. The exception to this trend is at the end of 2016, when the dynamics of the number of employees related to other forms of ownership is positive for both Bacau County and the Central Region.

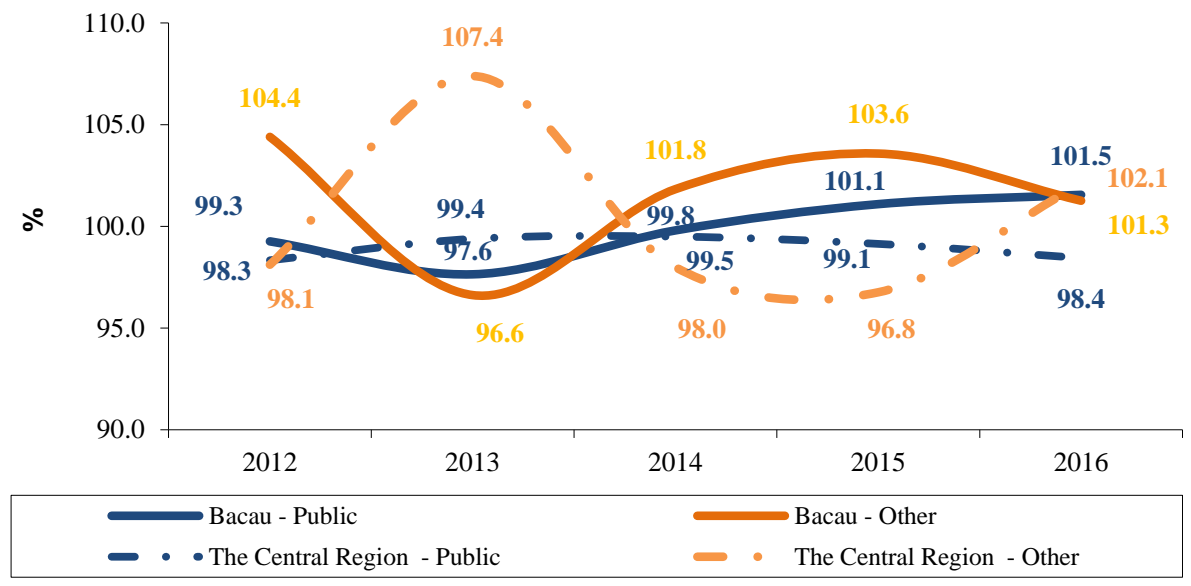

Figure 10: Dynamics of number of employees compared to previous year as at 31st December, by forms of ownership, Bacau County and the Central $\operatorname{Region}(\%)$

Source: processing of the data collected from www.insse.ro and www.statistica.md

The number of employees who worked at the end of 2016 in non-public ownership units was higher than at the end of 2011 in both Bacau County (+7.7\%) and the Central Region $(+2.0 \%)$. The decrease of this indicator in public ownership units may indicate a slight "migration" from the public sector to the other forms of ownership, for both the situations in Bacau County and the Central Region.

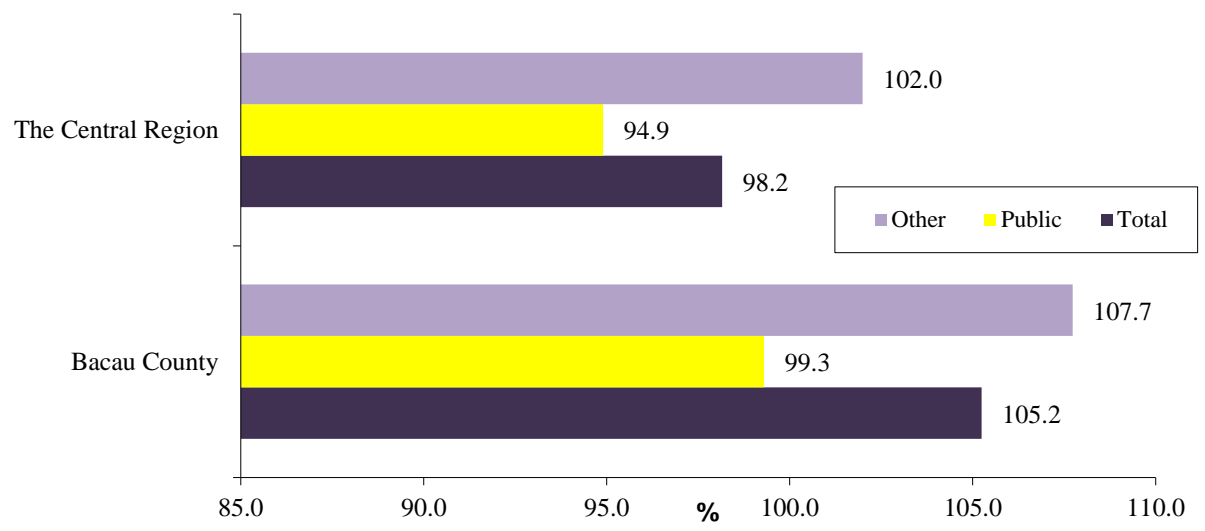

Figure 11: Dynamics of number of employees as at 31st December 2016, by forms of ownership, Bacau County and the Central Region (\%)

Source: processing of the data collected from www.insse.ro and www.statistica.md 


\section{Conclusions}

The analysis of the indicators that characterize the labour force situation of Bacau County in Romania as well as that of the Central Region of the Republic of Moldova, represented, in fact, the main objective pursued by the present paper.

Based on the above-mentioned data, we can conclude that in terms of the evolution of the number of employees as at 31 st December in Bacau County, this was a favourable, positive one, the values of this indicator increasing year by year, similar to the trend at national level, while in the Central Region this indicator has an oscillating trajectory, decreasing compared to 2011 but still in a slight increase compared to the previous year, actually following the trend of value of this indicator registered in the Republic of Moldova.

The number of female employees in the Central Region was significantly higher than the number of male employees for the entire 6-year period analysed, which is totally opposed to the case of Bacau County, where employees are predominantly male, 2014 being the only year that recorded at its end a number of female employees higher than the number of male employees.

The analysis of the number of employees of the two administrative units by forms of ownership indicates a decrease in the ratio of employment in public units, simultaneously with an increase in the ratio of employment in non-public ownership units. It is clear from the above mentioned data that there is an extremely large ratio of employees that activate at the end of 2016 in public sector units (over 50\%) in the Central Region, while in Bacau County the ratio of employees is only a few percent greater than $25 \%$.

\section{References}

Cole, G.A. (1997), Managementul personalului,Editura CODECS, Bucureşti.

Harja, Eugenia (2005), Analiza şi prognoza statistică a numărului şi structurii forţei de muncă, Editura Matrix Rom, Bucureşti.

Harja, Eugenia (2004), Statistica resurselor de muncă, Editura Matrix Rom, Bucureşti. Perţ, Steliana (coordonator) (1993), Potenţialul uman al unor ţări din spaţiul est şi sudest european, CIDE, Bucureşti.

BNS (2008), Organizarea muncii şi tipologia programului de muncă, BNS, Chișinău. BNS (2012), Piaţa muncii în Republica Moldova - Culegere statistică, BNS, Chişinău

INS, Statistics available at www.insse.ro

BNS, Statistic available at www.statistica.md 